\title{
Effect of Organic Substances and Plant Growth Regulators on Seed Germination and Survival of Tamarind (Tamarindus indica L.) Seedlings
}

\author{
Khushboo Tandon*, P.K.S. Gurjar, R. Lekhi and Deepa Soni \\ Department of Horticulture, College of Agriculture, RVSKVV-Gwalior, India \\ *Corresponding author
}

\begin{abstract}
A B S T R A C T
Keywords

Tamarindus indica, GA3, NAA, Cow urine

Article Info

Accepted:

18 January 2019

Available Online:

10 February 2019

Tamarind (Tamarindus indica L.), or Imli is also called Indian Date. It belongs to the family Leguminaceae. Tamarind is traditionally propagated from seed. Tamarind seeds exhibit poor germination percentage even if exposed to favourable conditions of germination owing to seed dormancy. Keeping in view, the present investigation was conducted during kharif season of 2017 at the horticulture nursery, College of Agriculture, Gwalior. In the present study seeds were imposed to twelve different treatments i.e. $\mathrm{T}_{0}$ Control (Soaking in distilled water), T GA $_{3} @ 100$ ppm, T GA $_{3} @ 200$ ppm, T $\mathrm{GA}_{3} @$ 300 ppm, T 4 NAA @ 100 ppm for 24 hr, T 5 NAA @ 200 ppm, T 6 NAA @ 300 ppm, T 7 Acid Scarification (HCL 10\%), $\mathrm{T}_{8}$ Cow urine 5\%, $\mathrm{T}_{9}$ Cow Urine 10\%, $\mathrm{T}_{10}$ Cow Urine $20 \%, \mathrm{~T}_{11}$ Cow Dung Slurry for $24 \mathrm{hr}$ and in acid $30 \mathrm{~min}$. The minimum days taken to start germination (5.27), maximum percentage of germination at 30 days $(86.67 \%)$ was recorded significantly under $\mathrm{T}_{2} \mathrm{GA}_{3} @ 200 \mathrm{ppm}$. But survival percentage of seedlings after 150 days $(94.67 \%)$ was found not significant. The minimum days taken to $50 \%$ germination (15.67) were recorded under $\mathrm{T}_{3} \mathrm{GA}_{3} @ 300$ ppm.
\end{abstract}

\section{Introduction}

Tamarind (Tamarindus indica L.), or Imli is also called Indian Date. It belongs to the family Leguminaceae. It is native to Tropical Africa, particularly in Sudan and also grown well in the tropical and semi-arid parts of India. India is the world's largest producer of tamarind products. In India, it is cultivated in 49,020 thousand ha area with the production of 1,90,700 MT (2016-17 Spices Board India). The major tamarind producing States are Tamil Nadu, Maharashtra, Karnataka, Andhra Pradesh, Madhya Pradesh and Kerala.
Tamarind plants are hard and drought tolerant. It has special importance in social, urban and agro forestry due to its multipurpose uses as industrial, pharmaceutical and commercial level. Almost all parts of the tree find a use in the food, chemical, pharmaceutical or textile industries, or as fodder, timber and fuel. Tamarind is a nutritious versatile fruit. The fruit consists mainly of pulp and seeds. Tamarind is valued highly for its pulp used in the preparation of food and beverages for domestic and industrial purposes. The pulp constitutes 30$50 \%$ of the ripe fruit, the shell and fiber 
account for $11-30 \%$ and the seed about 25 $40 \%$. The most outstanding characteristics of tamarind fruit is its acidic and sweet taste due to tartaric acid (10\%) and reducing sugars (30-40\%). The fruit, both ripe and dry, contains mainly tartaric acid, reducing sugars, pectin, tannin, fiber and cellulose. Plant growth regulators like $\mathrm{GA}_{3}$ and NAA enhance the germination, growth and survival of seedlings. $\mathrm{GA}_{3}$ is used for weakening of the seed coat so that the radical of the seedling can break through the seed coat. $\mathrm{GA}_{3}$ induced the synthesis of amylase and other hydrolytic enzymes during the early stages of seed germination. $\mathrm{GA}_{3}$ controls mobilization of starch which acts as a respiratory substrate leading to immediate enhancement in cell elongation. Gibberellins also help in enhancing the availability of reserved mineral elements which promote the germination process. The seed soaked in $\mathrm{GA}_{3}$ and NAA for 12 hour resulted in high germination and shoot length. The germination of tamarind seeds is also accelerated by soaking in $10 \%$ cow urine or cow dung solution $(500 \mathrm{~g}$ in 10 L) for 24 hours, in which germination is occurred more than doubled. The prices of growth regulators have gone sky high so to overcome this crisis some alternatives for growth regulators are easy to access and cheap. This has diverted the attention once again towards the chemical, cow urine which was in use as a growth regulator. Cow urine proving feasible may bring a breakthrough in the present context as it is free of cost and easily available through it is not much consistent. Cow urine contains Iron, urea, Uric acid, estrogen and progesterone which affect the inhibitory responses to seed germination, shoot growth and seedling vigour.

\section{Materials and Methods}

The experiment was conducted at nursery area, Department of Horticulture, College of
Agriculture, Gwalior (M.P.) during kharif season 2017. The topography of the area was uniform with proper drainage. The soil of the experimental field was sandy loam. The experimental field is located at an altitude of

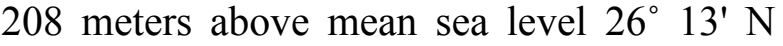
North latitude and $78^{\circ} 14^{\prime} \mathrm{E}$ longitude. The experimental design selected was Completely Randomized Design. All the treatments were replicated thrice. The treatments as follows:$\mathrm{T}_{0}$ - Control (Soaking in distilled water) for $24 \mathrm{hr}, \mathrm{T}_{1}-\mathrm{GA}_{3} @ 100 \mathrm{ppm}$ for $24 \mathrm{hr}, \mathrm{T}_{2}$ GA 3 @200 ppm for 24 hr, T T $_{3}$-GA $@ 300$ ppm for $24 \mathrm{hr}, \mathrm{T}_{4}$ - NAA @ 100 ppm for 24 hr, T5 - NAA@ 200 ppm for 24 hr, T 6 - NAA @ $300 \mathrm{ppm}$ for $24 \mathrm{hr}, \mathrm{T}_{7}$ - Acid Scarification (HCL 10\%) for $30 \mathrm{~min}, \mathrm{~T}_{8}-$ Cow urine $5 \%$ for $24 \mathrm{hr}, \mathrm{T}_{9}$ - Cow Urine $10 \%$ for $24 \mathrm{hr}, \mathrm{T}_{10}-$ Cow Urine $20 \%$ for $24 \mathrm{hr}, \mathrm{T}_{11}$ - Cow Dung Slurry for $24 \mathrm{hr}$ for breaking seed dormancy. After this seeds were shade dried for $10 \mathrm{~min}$ and then sown in Polybags of 12 " x 6" $(30 \mathrm{x}$ 15) size filled with a mixture of soil, sand, FYM in the ratio of $2: 1: 1$ at $0.5 \mathrm{~cm}$ depth in 2 $\mathrm{cm}$ apart and were kept in the shade house and watered daily till final data were recorded. Germination and survival parameters at definite intervals were recorded to find out the effect of these pre-treatments on germination of tamarind i.e. days taken to start germination, days taken to $50 \%$ germination, germination percentage at 30 days after sowing, survival percentage of seedlings at 150 days after sowing. The data collected during the investigation were analyzed statistically by the method of analysis of variance. The significance of various treatments was judged and suggested by R. A. Fisher (1954) applying ' $F$ ' test. Germination percentage was recorded based on the below mentioned formula:

Germination $(\%)=$

Total no. of seeds germinated $\times 100$

Total no. of seeds sown 


\section{Results and Discussion}

\section{Seed germination characters}

Pre-sowing treatments influenced germination characters of seeds, resulting in their improved germination (Table 1). The seeds subjected to growth regulator i.e. $\mathrm{GA}_{3} 200$ ppm for $24 \mathrm{hr}$ were recorded earliest germination (5.27 days). This was on par with seeds treated with $\mathrm{GA}_{3} 100 \mathrm{ppm}$ for $24 \mathrm{hr}$ (5.77 days), $\mathrm{GA}_{3} 300 \mathrm{ppm}$ for $24 \mathrm{hr}(6.10$ days), NAA $300 \mathrm{ppm}$ for $24 \mathrm{hr}$ (6.13 days), NAA $200 \mathrm{ppm}$ for $24 \mathrm{hr}$ (6.37 days) and NAA $100 \mathrm{ppm}$ for $24 \mathrm{hr}$ (6.83 days). The late (12.30 days) germination was noticed in control. The seed germination in tamarind is erratic due to the possession of various degrees of physical dormancy (Heit, 1967) caused due to hard seed coat, which is impermeable to water and oxygen (Bewley and Black, 1982). The treatment with $\mathrm{GA}_{3}$ $200 \mathrm{ppm}$ for 24 hours of soaking proved to be good treatment. Hence, due to involvement of $\mathrm{GA}_{3}$ activation of cytological enzymes takes place which increases in cell wall plasticity and better absorption of water. These findings are supported by Ram Chandra Sheo Govind (1990) in Guava, Parameshwari and Srimathi (2008) in Tamarind, Patel et al., (2016) in Mango, Vasantha et al., (2014) in Tamarind and Suradinata et al., (2017) in Christmas Palm.

The minimum days taken to $50 \%$ germination (15.67) were recorded under $\mathrm{GA}_{3} @ 300 \mathrm{ppm}$ for $24 \mathrm{hr}$. This was on par with $\mathrm{GA}_{3} 200 \mathrm{ppm}$ for $24 \mathrm{hr}$ ( 16.00 days), NAA $300 \mathrm{ppm}$ for $24 \mathrm{hr}$ (16.33 days), $\mathrm{GA}_{3} 100 \mathrm{ppm}$ for $24 \mathrm{hr}(16.67$ days) and NAA $200 \mathrm{ppm}$ for 24hr (16.67 days) and maximum days taken by control treatment i.e. 26.67. The promising effect of $\mathrm{GA}_{3}$ on seed germination might be due to its participation in the activity of alpha-amylase, which catalyzes the starch conversion in to simple carbohydrates and chemical energy is liberated which is used in the activation of embryo. Similar result has been reported by Pawar et al., (2010) and Lay et al., (2015).

Table.1 Effect of organic substance, scarification and plant growth regulators on seed germination characters of tamarind seeds

\begin{tabular}{|l|c|c|c|}
\hline Treatment & $\begin{array}{c}\text { Days taken to } \\
\text { start germination }\end{array}$ & $\begin{array}{l}\text { Days taken to 50\% } \\
\text { germination }\end{array}$ & $\begin{array}{l}\text { Percentage of } \\
\text { germination at 30 } \\
\text { DAS. }\end{array}$ \\
\hline $\mathbf{T}_{\mathbf{0}}$ & 12.30 & 26.67 & 58.67 \\
\hline $\mathbf{T}_{\mathbf{1}}$ & 5.77 & 16.67 & 82.67 \\
\hline $\mathbf{T}_{\mathbf{2}}$ & 5.27 & 16.00 & 86.67 \\
\hline $\mathbf{T}_{\mathbf{3}}$ & 6.10 & 15.67 & 81.33 \\
\hline $\mathbf{T}_{\mathbf{4}}$ & 6.83 & 18.00 & 66.67 \\
\hline $\mathbf{T}_{\mathbf{5}}$ & 6.37 & 16.67 & 72.00 \\
\hline $\mathbf{T}_{\mathbf{6}}$ & 6.13 & 16.33 & 73.33 \\
\hline $\mathbf{T}_{\mathbf{7}}$ & 7.20 & 19.00 & 68.00 \\
\hline $\mathbf{T}_{\mathbf{8}}$ & 8.57 & 22.00 & 60.00 \\
\hline $\mathbf{T}_{\mathbf{9}}$ & 8.53 & 24.33 & 65.33 \\
\hline $\mathbf{T}_{\mathbf{1 0}}$ & 8.50 & 22.00 & 69.33 \\
\hline $\mathbf{T}_{\mathbf{1 1}}$ & 9.13 & 24.67 & 70.67 \\
\hline $\mathbf{S E m} \mathbf{D}$ & $\mathbf{0 . 2 6 9}$ & $\mathbf{0 . 7 8 8}$ & $\mathbf{1 . 6 3 3}$ \\
\hline $\mathbf{C D}$ at 5\% & $\mathbf{0 . 7 8 4}$ & $\mathbf{2 . 2 9 9}$ & $\mathbf{4 . 7 6 7}$ \\
\hline
\end{tabular}


Table.2 Effect of organic substance, scarification and plant growth regulators on survival percentage of seedlings after 150 days of tamarind seedlings

\begin{tabular}{|c|c|}
\hline Treatment & $\begin{array}{c}\text { Survival percentage of } \\
\text { seedlings after 150 days }\end{array}$ \\
\hline $\mathbf{T}_{\mathbf{0}}$ & 90.67 \\
\hline $\mathbf{T}_{\mathbf{1}}$ & 93.33 \\
\hline $\mathbf{T}_{\mathbf{2}}$ & 94.67 \\
\hline $\mathbf{T}_{\mathbf{3}}$ & 89.33 \\
\hline $\mathbf{T}_{\mathbf{4}}$ & 89.33 \\
\hline $\mathbf{T}_{\mathbf{5}}$ & 93.33 \\
\hline $\mathbf{T}_{\mathbf{6}}$ & 88.00 \\
\hline $\mathbf{T}_{\mathbf{7}}$ & 86.67 \\
\hline $\mathbf{T}_{\mathbf{8}}$ & 88.00 \\
\hline $\mathbf{T}_{\mathbf{9}}$ & 86.67 \\
\hline $\mathbf{T}_{\mathbf{1 0}}$ & 93.33 \\
\hline $\mathbf{T}_{\mathbf{1 1}}$ & 89.33 \\
\hline $\mathbf{S E m} \pm$ & $\mathbf{4 . 1 8 1}$ \\
\hline $\mathbf{C D}$ at 5\% & $\mathbf{N S}$ \\
\hline
\end{tabular}

The maximum percentage of germination at 30 days $(86.67 \%)$ was recorded significantly under $\mathrm{GA}_{3} @ 200 \mathrm{ppm}$ for $24 \mathrm{hr}$. This was on par with $\mathrm{GA}_{3} @ 100 \mathrm{ppm}$ for $24 \mathrm{hr}(82.67)$ and $\mathrm{GA}_{3} @$ $300 \mathrm{ppm}$ for $24 \mathrm{hr}$ (81.33) whereas minimum value of 58.67 percent germination was recorded under control treatment. It might be due to $\mathrm{GA}_{3}$ which would have triggered the activity of specific enzymes that promoted early germination, such as $\alpha$-amylase, which have brought an increase in availability of starch assimilation. Similar work has been reported by Parameshwari and Srimathi (2008), Sharma et al., (2016) and Samir Malaya et al., (2015).

\section{Survival percentage of tamarind seedling}

The maximum survival percentage of seedlings $94.67 \%$ was recorded under $\mathrm{GA}_{3} 200 \mathrm{ppm}$ for $24 \mathrm{hr}$ while minimum survival percentage of seedling $86.67 \%$ was recorded under HCL $10 \%$ and Cow urine $10 \%$ at 150 days after seed sowing. This result has been supported by Ak et al., (1995), Ramteke et al., (2015) and Chiranjeevi et al., (2017) revealed that by treating with $\mathrm{GA}_{3}$ at $200 \mathrm{ppm}$ are well known for better germination, seedling growth and vigour are highly suitable for commercial cultivation and their germination and seedling health can be improved. The result found here show non significant effect on survival percentage of seedlings (Table 2).

From the present investigation, it was concluded that, days taken to start germination, days taken to $50 \%$ germination, germination percentage at 30 days after sowing and survival percentage of seedlings at 150 days after sowing was noticed in seeds subjected to application of $\mathrm{GA}_{3} 200 \mathrm{ppm}$ for $24 \mathrm{hr}$. Finally, it is concluded that the plant growth regulator $\left(\mathrm{GA}_{3} 200 \mathrm{ppm}\right)$ was found superior over rest of the plant growth regulators and cow urine, under study, which was significantly influenced the germination and survival of tamarind. It affect significantly all the recorded parameters. As regards $\mathrm{GA}_{3}$ is significantly encourage to germination, growth and survival of tamarind seedlings. 


\section{References}

Ak BE, Ozguven AI and Nikpeyma Y. (1995). The effect of GA3 application on Pistachio nut seed germination and seedling growth. Acta Horti., 419:115-120.

Bewley, J. D. and B. M. Black (1982). Physiology and biochemistry of seed germination. Part II, Springer Verlag, New York.

Chiranjeevi, M.R., Muralidhara, B.M., Sneha, M.K., Shivan and Hongal (2017). Effect of Growth Regulators and Biofertilizers on Germination and Seedling Growth of Aonla (Emblica officinalis Gaertn). Int.J.Curr.Microbiol.App.Sci. 6(12): 13201326.

Heit, C. E. (1967). Propagation from seed. Am. Nursery man., 125(12): 10-11, 37-41, 4445.

Lay, Padma; Basvarraju, G.V., Pashte V.V. and Gowri, M. (2015). Studies on effect of giberellic acid $\left(\mathrm{GA}_{3}\right)$ and potassium nitrate $\left(\mathrm{KNO}_{3}\right)$ on breaking of seed dormancy of Papaya (Carica papaya L.) cv. Surya.

Parameshwari, K. and Srimathi, P. (2008). Influence of growth regulators on elite seedling production in Tamarind (Tamarindus indica L.). Legume Research, 31 (4): 300-302.

Patel, R.J., Ahlawat, T.R., Singh, Alka; Momin, S.K., and Chaudhri, Gavri, (2016). Effect of pre-sowing treatments on stone germination and shoot growth of Mango (Mangifera indica L.) seedlings. International Journal of Agriculture Sciences, 8(52): 2437-2440.

Pawar, V.B., Gore, R.V., Patil, V.K. and Narsude, P.B. (2010). Effect of gibberellic acid on seed germination and growth of Jatropha curcas L., Asian J. Hort., 5 (2): 311-313.

Ramteke, Vikas; Paithankar, D. H., Ningot, Ekta P., and Kurrey Vivek Kumar (2015). Effect of $\mathrm{GA}_{3}$ and propagation media on germination, growth and vigour of Papaya cv. Coorg Honey Dew. An Int. Quarterly J. of Life Sci. 10(3): 1011-1016.

Ram Chandra Sheo Govind (1990). Gibberellic acid, thiourea, Ethrel and acid treatments in relation to seed germination and seedling growth in Guava (Psidium guajava L.). Progressive Horticulture. 22(1-4):40-43.

Suradinata, Yayat Rochayat; Nuraini, Anne; and Ruminta (2017). Effect of Concentration and Length Time of Soaking Seed in Gibberellic Acid $\left(\mathrm{GA}_{3}\right)$ on Germination and Growth of Christmas Palm (Veitchia merilli (Beec) H. F. Moors). International Journal of Science and Research (IJSR), 6(11): 492-495.

Sharma, D.K. (2016). Effect of Growth Regulators, Bio fertilizer and scarification on Germination and Seedling Growth of Tamarind. Advances in life science, 5(7): 2818-2823.

Samir, Malay; Rai, Ratna; and Prasad, Birendra (2015). Seed germination behaviour as influenced by pre-sowing treatments in Khirni. Journal of Hill Agriculture, 6(1): 132-135.

Vasantha, P. T., Vijendrakumar, R. C., Guruprasad, T. R., Mahadevamma, M. and Santhosh, K.V. (2014). Studies on effect of growth regulators and biofertilizers on seed germination and seedling growth of Tamarind (Tamarindus indica L.). Plant Archives, 14(1): 155-160.

\section{How to cite this article:}

Khushboo Tandon, P.K.S. Gurjar, R. Lekhi and Deepa Soni. 2019. Effect of Organic Substances and Plant Growth Regulators on Seed Germination and Survival of Tamarind (Tamarindus indica L.) Seedlings. Int.J.Curr.Microbiol.App.Sci. 8(02): 2270-2274. doi: https://doi.org/10.20546/ijcmas.2019.802.264 